\title{
Reassessment of Allantonectria, phylogenetic position of Thyronectroidea, and Thyronectria caraganae sp. nov.
}

\author{
${\text { Hermann } \operatorname{Voglmayr}^{1}{ }^{1} \text { - Olexander Yu. Akulov }}^{2} \cdot$ Walter M. Jaklitsch ${ }^{1,3}$
}

Received: 6 May 2016 / Revised: 10 July 2016/Accepted: 14 July 2016/Published online: 9 August 2016

(C) The Author(s) 2016. This article is published with open access at Springerlink.com

\begin{abstract}
The genus Allantonectria is synonymised with Thyronectria, based on morphological and molecular phylogenetic considerations. Investigations of types and fresh collections revealed that Tubercularia concentrica is an earlier name for Sphaeria (syn. Allantonectria) miltina and is thus combined in Thyronectria. Allantonectria yuccae is recognised as a distinct species and transferred to Thyronectria, as well as the recently described A. zangii. Descriptions and illustrations are provided for T. concentrica and T. yuccae. A recent collection of the North American Thyronectroidea chrysogramma, the generic type of Thyronectroidea, was studied with respect to morphology of its sexual morph in fresh condition and of its asexual morph produced in pure culture. Molecular phylogenies based on six loci (ITS and LSU regions of nuc rDNA, act1, rpbl, $r p b 2$, tef1 and tub2 genes) place T. chrysogramma within Thyronectria, confirming synonymy of Thyronectroidea with Thyronectria, but remarkably a relationship to European species with green to brown spores (former genus Mattirolia) receives no support, and its closest relatives remain unclear.
\end{abstract}

Section Editor: Gerhard Rambold

Hermann Voglmayr

hermann.voglmayr@univie.ac.at

1 Division of Systematic and Evolutionary Botany, Department of Botany and Biodiversity Research, University of Vienna, Rennweg 14, 1030 Wien, Austria

2 V. N. Karazin Kharkiv National University, Maidan Svobody 4, 61022 Kharkiv, Ukraine

3 Institute of Forest Entomology, Forest Pathology and Forest Protection, Department of Forest and Soil Sciences, BOKU-University of Natural Resources and Life Sciences, Hasenauerstraße 38, 1190 Wien, Austria
Thyronectria caraganae is described as a new species from herbarium specimens of Caragana arborescens collected in the Ukraine. It is characterised by morphology of the sexual morph and by DNA sequence data, which place it within the T. austroamericana - T. rhodochlora clade with high support. This is also supported by its morphology, specifically ascomata partly embedded within a stroma, muriform ascospores not budding within the ascus, becoming yellowish to rosy at maturity.

Keywords Ascomycota $\cdot$ Hypocreales $\cdot$ Nectriaceae . Phylogenetic analysis $\cdot$ Sordariomycetes $\cdot$ Taxonomy

\section{Introduction}

The genus Thyronectria was recently re-instated by Jaklitsch and Voglmayr (2014), as it takes precedence over the younger genus Pleonectria. Based on detailed morphological as well as molecular phylogenetic analyses, they synonymised Mattirolia, Pleonectria and Thyronectroidea with Thyronectria and combined all respective epithets in Thyronectria. This was also implemented by Lombard et al. (2015) in their overview of genera of the Nectriaceae.

Morphologically, the genus Thyronectria is mainly characterised by nectriaceous ascomata with a yellow scurf at the outer surface in combination with long, more or less persistent, apical paraphyses (Jaklitsch and Voglmayr 2014). Ascospores within the genus are highly diverse in size, shape, colour and septation; they can be ellipsoid, oblong, fusiform, globose, clavate or vermiform, with eusepta and/or distosepta, one- to several-septate or muriform, smooth or striate, and their colour can be hyaline, yellowish, rosy, green or brown. In several species, ascospores are budding in the ascus to produce oblong to allantoid, 1-celled, hyaline ascoconidia. 
Ecologically, several species have commonly been found in association with effete pyrenomycetes, indicating that they are fungicolous.

Subsequently, Checa et al. (2015) described two new Thyronectria species with olivaceous to green-brown muriform ascospores from Spain. In the phylogenetic analyses, the four known European Thyronectria species with green to brown muriform ascospores (T. asturiensis, T. giennensis, $T$. pistaciae and $T$. roseovirens) formed a highly supported subclade, together with $T$. obscura, which has hyaline muriform, budding ascospores.

The lack of fresh collections and cultures precluded the inclusion of the North American Thyronectroidea chrysogramma, which also has greenish to brown muriform ascospores, in molecular phylogenetic analyses. Based on morphological investigations, it was included in Mattirolia by Checa et al. (2013), while Jaklitsch and Voglmayr (2014) provided convincing arguments for a placement within Thyronectria. A recent Canadian collection from the type host, Ulmus americana, enabled us to document its sexual morph in fresh condition, to study its asexual morph produced in pure culture and to assess its phylogenetic position by DNA sequence data.

In the course of a revision of herbarium specimens at the $\mathrm{V}$. N. Karazin Kharkiv National University, Ukraine (CWU), several specimens of an unidentified nectriaceous fungus were revealed on Caragana arborescens. All specimens were originally deposited at the M.G. Kholodny Institute of Botany, NAS of Ukraine, Kyiv (KW). Although their characters matched the genus Thyronectria, they could not be identified with the keys of Jaklitsch and Voglmayr (2014) and Checa et al. (2015). DNA sequence data subsequently obtained from ascomata confirmed an affiliation with Thyronectria, and following molecular phylogenetic and morphological analyses, it is here described as a new species.

The genus Allantonectria (Earle 1901) has been revealed as closely related to Thyronectria in molecular phylogenies with high support (Hirooka et al. 2012; Jaklitsch and Voglmayr 2014; Checa et al. 2015; Lombard et al. 2015). Hirooka et al. (2012) accepted Allantonectria as a separate monotypic genus, characterized by minute, one-celled allantoid to rodshaped ascospores and growth on monocotyledonous hosts as diagnostic characters. In previous works (Höhnel and Weese 1910; Lowen 1991; Hirooka et al. 2012), the generic type of Allantonectria, A. yuccae from Yucca spp., was regarded as a synonym of $A$. miltina, which was described from Agave americana. However, none of these authors mentioned Tubercularia concentrica, although this species was considered to be the asexual morph of A. miltina in the older literature (e.g., Saccardo 1878, 1883) and which, in case of conspecificity, would take precedence due to priority.

The description of $A$. zangii from Populus sp. (Zeng and Zhuang 2012, 2013), a non-monocotyledonous host, and the lack of significant support for a sister group relationship of Thyronectria to Allantonectria in recent molecular phylogenies (Jaklitsch and Voglmayr 2014; Checa et al. 2015) called for a re-evaluation of the generic status of Allantonectria. We performed detailed morphological studies of Allantonectria specimens from Agave and Yucca spp. for comparison with Thyronectria and to evaluate the species status of A. miltina and $A$. yuccae. In addition, we examined the types and fresh collections of Tubercularia concentrica and A. miltina to investigate whether they are conspecific. Based on these investigations, we conclude that $T$. concentrica and $A$. miltina are synonymous, A. yuccae represents a distinct species and Allantonectria should be merged with Thyronectria.

\section{Materials and methods}

\section{Morphological observations}

Microscopic preparations were mounted in water, $3 \%$ potassium hydroxide $(\mathrm{KOH})$ or lactic acid (LA). Methods of microscopy included stereomicroscopy using a Nikon SMZ 1500 and Nomarski differential interference contrast (DIC) using the Zeiss Axio Imager.A1 compound microscope. Images and data were gathered using the Nikon DS-U2 or Zeiss Axiocam 506 color digital cameras and measured by using the NIS-Elements D v.3.0 or Zeiss ZEN Blue Edition softwares. For certain images of ascomata the stacking software Zerene Stacker v.1.04 (Zerene Systems, Richland, WA, USA) was used. Measurements are reported as maxima and minima in parentheses and the range representing the mean plus and minus the standard deviation of a number of measurements given in parentheses.

\section{Culture observations}

Due to lack of fresh material of Thyronectria caraganae, no cultures could be obtained. Cultures of T. chrysogramma and T. concentrica were prepared and maintained as described previously (Jaklitsch 2009) except that $2 \%$ malt extract agar (MEA) was used for isolation. Germinating ascospores/ conidia were placed on MEA and CMD (CMA: Sigma, St Louis, MI, USA; supplemented with $2 \%(\mathrm{w} / \mathrm{v}) \mathrm{D}(+)$-glucose-monohydrate) or $2 \%$ malt extract agar (MEA; $2 \% \mathrm{w} / \mathrm{v}$ malt extract, $2 \% \mathrm{w} / \mathrm{v}$ agar-agar; Merck, Darmstadt, Germany). Cultures used for the study of asexual morph micro-morphology were grown on $2 \% \mathrm{MEA}$ or CMD at room temperature (RT; $22 \pm 3{ }^{\circ} \mathrm{C}$ ) under alternating $12 \mathrm{~h}$ daylight and $12 \mathrm{~h}$ darkness. Microscopic observations were made in tap water except where noted. The plates were sealed with laboratory film and incubated at room temperature. A culture of T. chrysogramma was deposited at CBS-KNAW Fungal Biodiversity Centre, Utrecht, The Netherlands (CBS). 


\section{DNA extraction, PCR and sequencing}

The extraction of genomic DNA, PCR and sequencing of segments of six loci, i.e., the nuc rDNA region encompassing the internal transcribed spacers 1 and 2 , along with the $5.8 \mathrm{~S}$, and the D1-D2 domains of the $28 \mathrm{~S}$ (ITS-LSU), $\alpha$-actin (actl) gene, RNA polymerase II subunit $1(r p b 1)$ and subunit $2(r p b 2)$ genes, translation elongation factor $1-\alpha(t e f 1)$ gene, and $\beta$-tubulin (tub2) gene, was performed as reported in Jaklitsch and Voglmayr (2014), but using the newly designed primers dRPB2-5f (5' GAYACNGAYGAYCGWGAYCAYTTYGG 3') and dRPB2-7r (5' AANCCCATDGCYTGYTTDCCCAT 3') for amplification and sequencing of $r p b 2$. As no living cultures were available for T. caraganae, DNA was directly extracted from ascomata using the protocol described in Voglmayr and Jaklitsch (2011).

\section{Phylogenetic analyses}

A single accession of each Thyronectria species was included in the phylogenetic analyses. The accessions were selected according to availability of markers and, if possible, ex-type sequences were used (marked with an asterisk in Fig. 1). In addition, four Nectria species were included, and Septofusidium berolinense, S. herbarum and Tilachlidium brachiatum (Tilachlidiaceae) were selected as outgroup according to Lombard et al. (2015). Available sequences were downloaded from GenBank; details on the sequences used in the phylogenetic analyses are provided in Table 1 .

All alignments were produced with the server version of MAFFT (www.ebi.ac.uk/Tools/mafft or http://mafft.cbrc. jp/alignment/server/), checked and refined using BioEdit v.7.0.4.1 (Hall 1999). To reveal the phylogenetic position of the newly sequenced Thyronectria species, the newly generated sequences were aligned with the GenBank sequences. The resulting combined sequence matrix contained 6292 alignment positions from six gene regions (630 from actl, 541 from ITS and 807 from LSU, 706 from $r p b 1,1192$ from rpb2, 1308 from tef1 and 1108 from tub2).

Maximum likelihood (ML) analyses were performed with RAxML (Stamatakis 2006) as implemented in raxmlGUI 1.3 (Silvestro and Michalak 2012) using the ML+ rapid bootstrap setting and the GTRGAMMAI substitution model with 1000 bootstrap replicates. Substitution model parameters were calculated separately for the different gene regions included in the combined analyses.

Maximum parsimony (MP) analyses were performed with PAUP v.4.0a147 (Swofford 2002), using 1000 replicates of heuristic search with random addition of sequences and subsequent TBR branch swapping (MULTREES option in effect, steepest descent option not in effect). All molecular characters were unordered and given equal weight; analyses were performed with gaps treated as missing data; the COLLAPSE command was set to MAXBRLEN. Bootstrap analysis with 1000 replicates was performed in the same way, but using 5 rounds of random sequence addition and subsequent TBR branch swapping during each bootstrap replicate, with the COLLAPSE command set to MINBRLEN.

\section{Results}

\section{Cultures and sequences of sexual and asexual morphs of Thyronectria concentrica}

Growth characteristics of cultures of $T$. concentrica obtained from the presumed asexual morph matched those obtained from ascospores, and the asexual morph produced in pure cultures from ascospores and conidia was identical. The ITS-LSU sequences of cultures isolated from the sexual and asexual morphs were identical to GenBank sequences of Allantonectria miltina from Agave americana.

\section{Molecular phylogeny}

Of the 6292 characters of the combined matrix, 1857 were parsimony informative (142 in act1, 119 in ITS, 108 in LSU, 304 in rpb1, 485 in rpb2, 393 in tef1 and 306 in tub2). The phylogram of the best ML tree $(\operatorname{lnL}=-49176.5326)$ obtained by RAxML is shown in Fig. 1. The MP analysis revealed a single tree of length 9703 (not shown), which is similar to the ML tree except for a different position of T. chrysogramma (see below), a sister group relationship of Nectria dematiosa to the other three Nectria species, and a placement of $T$. quercicola following next to $T$. berolinensis. Except for minor differences, tree topologies agree well with those of Jaklitsch and Voglmayr (2014) and Checa et al. (2015).

The Thyronectria-Allantonectria clade is highly supported in both ML and MP analyses (Fig. 1), Allantonectria receives maximum support, but Thyronectria receives only low support. The ML and MP analyses reveal different phylogenetic positions of $T$. chrysogramma. In the ML analyses, Thyronectria chrysogramma is placed basal to the highly supported clade containing species with yellowish to rosy spores, but this placement does not receive ML bootstrap support. In the MP analysis, T. chrysogramma is the most basal taxon of the Allantonectria-Thyronectria clade, however, again without bootstrap support. Thyronectria caraganae is placed in the highly supported clade containing species with yellowish to rosy spores; sister group relationship to T. austroamericana receives low (MP) or high (ML) support. 
Fig. 1 Phylogram of the best maximum likelihood tree $(\operatorname{lnL}=-49176.5326)$ revealed by RAxML from an analysis of the combined matrix of Thyronectria, showing the phylogenetic position of T. chrysogramma and T. caraganae (in bold). ML and MP bootstrap support above $50 \%$ are given above or below the branches. Strain or herbarium numbers are given following the taxon names; holo-, neo- or epitype strains/specimens are marked by an asterisk (*). The tree was rooted with Septofusidium berolinense, S. herbarum and Tilachlidium brachiatum (Tilachlidiaceae) according to Lombard et al. (2015)

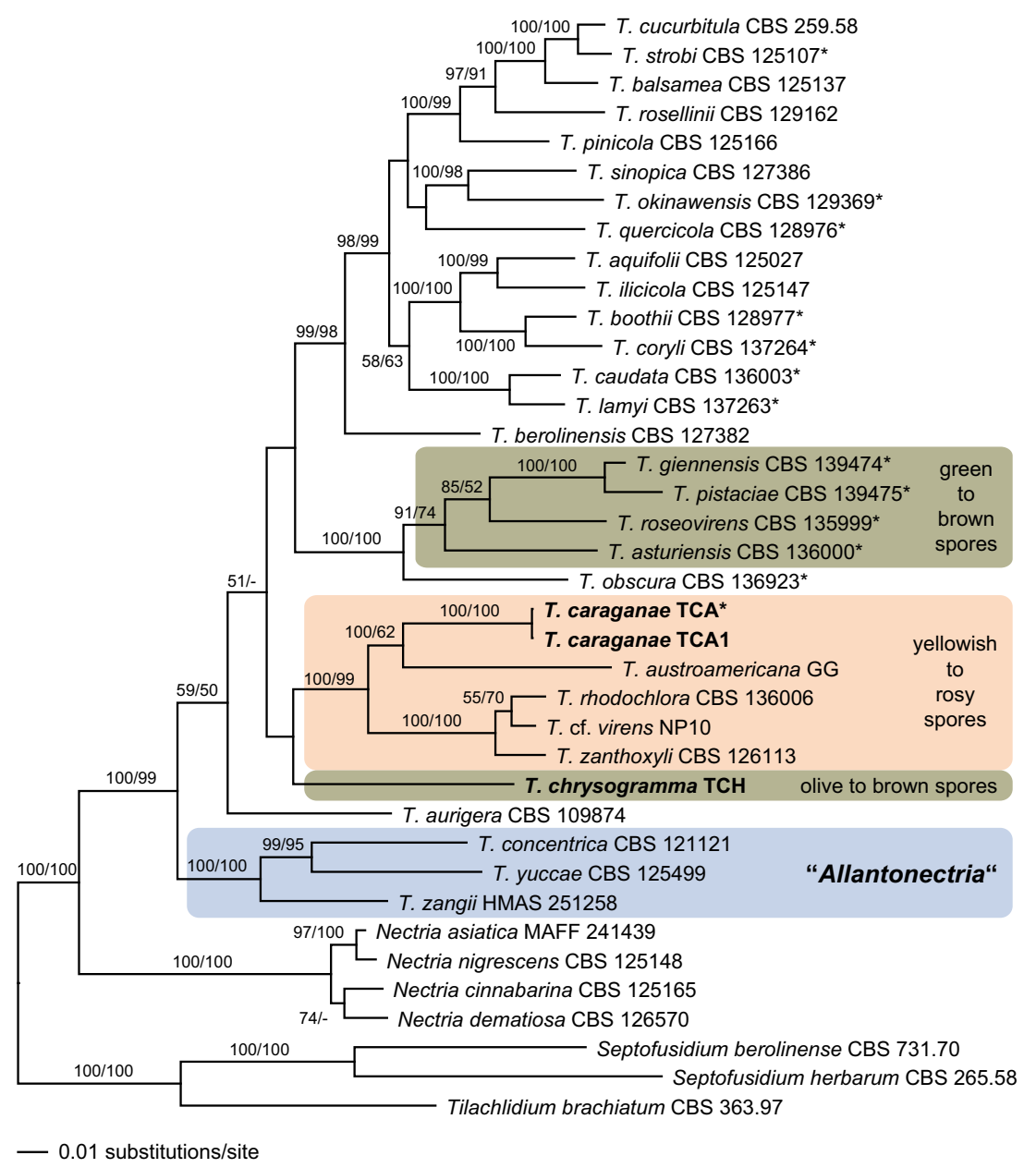

\section{Taxonomy}

Thyronectria caraganae Voglmayr, Akulov \& Jaklitsch, sp. nov. Fig. 2.

MycoBank: MB 817627.

Etymology: referring to its host, Caragana arborescens.

Stromata erumpent from bark, surrounded by bark flaps or projecting above the bark level; stromatic tissue surrounding ascomata that are densely aggregated in numbers of up to ca. 120 in 1.2-3.2(-4.4) $\mathrm{mm}$ long, 0.9-2.8(-3.1) $\mathrm{mm}$ wide $(n=19)$ and $0.7-1.5 \mathrm{~mm}$ high, rounded or elongated clusters. Ascomata globose to obovoid, not becoming cupulate upon drying, (275-)320-420(-530) $\mu \mathrm{m}$ diam in surface view $(n=92)$, ca. $330-430 \mu \mathrm{m}$ high when dry, varying in colour from yellow to dull olive brown, turning orange-red in $3 \%$ $\mathrm{KOH}$, entirely covered by greenish-yellow scurf of minute amorphous particles when young; scurf vanishing around the ostiolar region with age. Peridium 30-45 $\mu \mathrm{m}$ thick at the base, ca. $45-70 \mu \mathrm{m}$ at the sides, consisting of a thin (ca. 10$15 \mu \mathrm{m})$ hyaline to yellowish inner layer of strongly compressed, elongate (4.5-)6-10(-12) $\mu \mathrm{m}(n=20)$ long cells and an outer ca. $20-55 \mu \mathrm{m}$ thick layer of thick-walled, compressed cells $(6.5-) 7.5-14(-19) \mu \mathrm{m}(n=40)$ diam, tending to be more isodiametric outward, pigmented from the outside to the inside dark orange/yellow-orange/yellow in $3 \% \mathrm{KOH}$, releasing yellow pigment in $\mathrm{KOH}$; without a distinct $\mathrm{pH}-$ dependent colour change in $\mathrm{KOH}$ and LA. Ostiolar region $(30-) 43-71(-90) \mu \mathrm{m}$ diam in surface view $(n=68)$ when dry, slightly papillate or flat-umbilicate, darker than the main part of the ascoma, dark olive-brown to black. Ostiole periphysate, ca. 16-27 $\mu \mathrm{m}$ wide in surface view when dry. Periphyses pointed, short, 15-30(-40) $\mu \mathrm{m}$ long, 2-3 $\mu \mathrm{m}$ wide, projecting into the ostiole and slightly downward. Apical paraphyses numerous, indistinct in $\mathrm{KOH}$, embedded in a slime matrix when immature, hanging down to the base of the asci, richly branched and anastomosing, 2-4 $\mu \mathrm{m}$ wide. Asci clavate, $(78-) 85-103(-118) \times(12-) 15-19(-22) \mu \mathrm{m}$ $(n=57)$, with variable stipe and undifferentiated apex, containing 8 obliquely uniseriate or biseriate ascospores. Ascospores ellipsoid or oblong, straight or curved, $(14.3-) 18-24(-28.4) \times(4.8-) 6.3-7.7(-9.2) \mu \mathrm{m}$, $1 / \mathrm{w}=(1.9-) 2.5-3.5(-4.4)(n=272)$, muriform, with $(5-) 7(-10)$ transverse and $(0-) 1(-2)$ longitudinal, less commonly oblique septa, hyaline and often more oblong when immature, turning yellowish to rosy at full maturity, smooth, not budding in the ascus. 


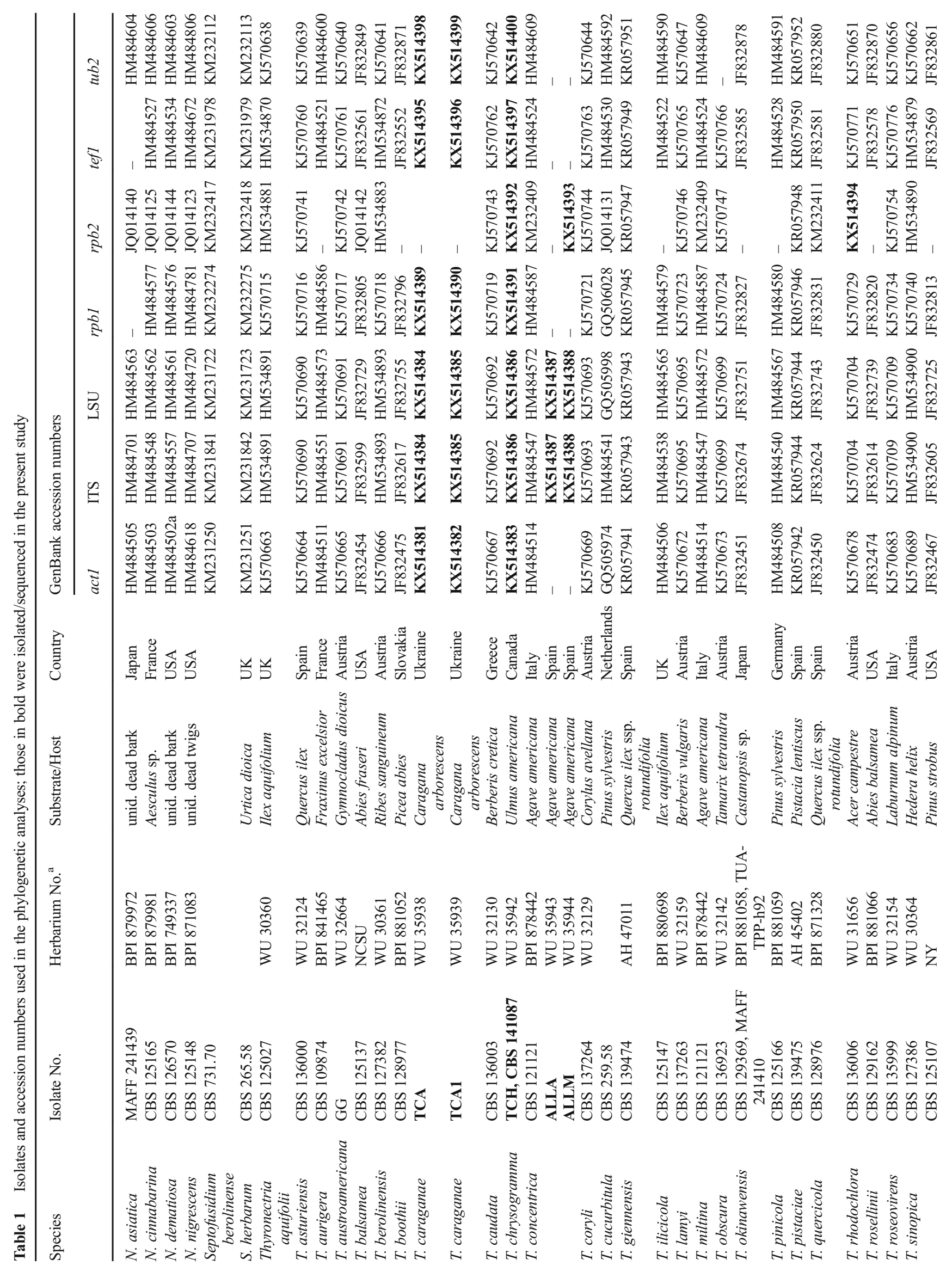




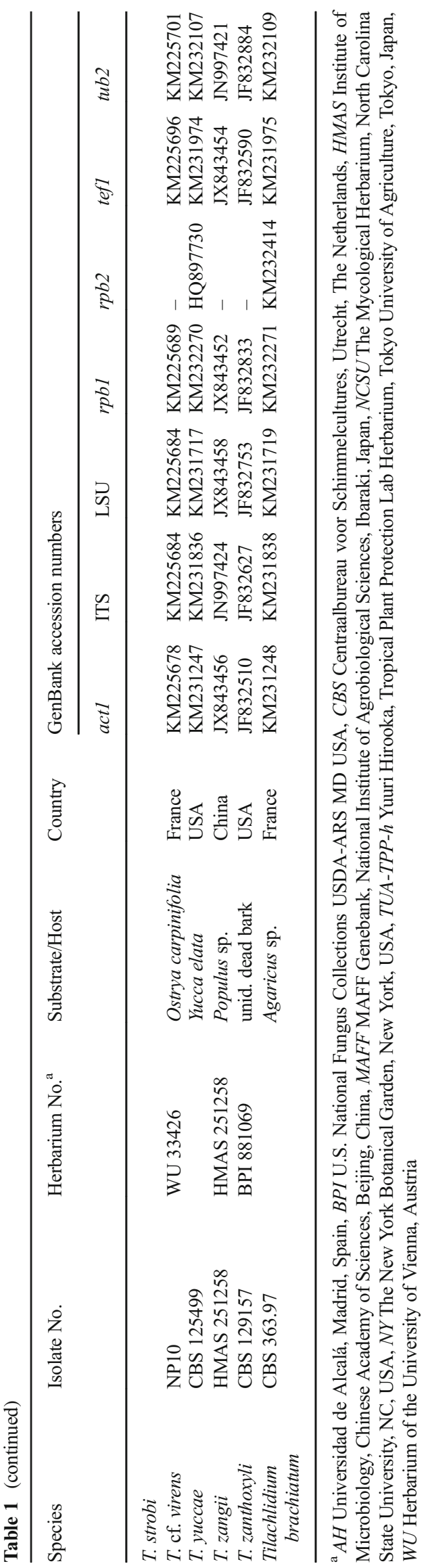

Fig. 2 Thyronectria caraganae. a-e Stromata/ascomata. $\mathbf{f}-\mathbf{h}$ Peridium in vertical section (f ostiolar region; $\mathbf{g}$ base; $\mathbf{h}$ side; in $3 \% \mathrm{KOH}$ ). $\mathbf{i}-\mathbf{l}$ Asci with ascospores (i with apical paraphyses; $\mathbf{j}, \mathbf{k}$ immature; $\mathbf{I}$ mature; $\mathbf{i}, \mathbf{I}$ in $3 \% \mathrm{KOH} ; \mathbf{j}, \mathbf{k}$ in Congo Red). $\mathbf{m}-\mathbf{r}$ Ascospores (o immature; all in $3 \%$ $\mathrm{KOH})$. a, e-k, o, p WU 35938; b WU 35941; c, d WU 35940; m, n, q, r WU 35939. Scale bars (a-c) $500 \mu \mathrm{m}$; (d, e) $200 \mu \mathrm{m} ;(\mathbf{f}-\mathbf{I}) 20 \mu \mathrm{m} ;(\mathbf{m}-\mathbf{r})$ $10 \mu \mathrm{m}$

Asexual morph: Not observed.

Distribution: Eastern Europe, only known from the Ukraine.

Ecology: On dead corticated branches of Caragana arborescens; possibly fungicolous and associated with Cucurbitaria caraganae.

Holotype: Ukraine, Mykolaiv district, Berezansky area, Tashine, on Caragana arborescens, 16 May 1990, L.V. Smyk (WU 35938 holotype, KW 7033/8583 and CWU (MYC) AS374 isotypes; ex-holotype sequences KX514384 (ITS-LSU rDNA), KX514381 (act1), KX514389 (rpb1), KX514395 (tef1), KX514398 (tub2)).

Other material studied: Ukraine, Donets'k district, Volnovachasky area, Ol'shanka, on Caragana arborescens, 31 July 1986, L.V. Smyk (KW 7419/7853, CWU (MYC) AS430, WU 35939); Dnipropetrovs'k district, Pjatihatsky area, along motorway Dnipropetrovs'k - Pjatihatky, on Caragana arborescens, 10 Oct. 1973, L.V. Smyk (KW 7418/7852, CWU (MYC) AS429, WU 35941); Zaporizhzhya district, Akimovsky area, Bogatyrskoe forest, on Caragana arborescens, 19 Jan. 1972, M.F. Smitskaya (KW 7417/7851, CWU (MYC) AS428, WU 35940).

Notes: The lack of fresh material precluded pure culture isolation, but sequencing of DNA extracted from ascomata revealed sequences of five of the six loci used in the phylogenetic analyses. Thyronectria caraganae is well characterised by the dull olive-brown ascomata surrounded by stromatic tissue covered by a greenish-yellow scurf, which are usually densely aggregated in large numbers; the hyaline to yellowish or rosy elongate-ellipsoid muriform ascospores with usually seven indistinct transverse septa and typically a single longitudinal septum; and its host, Caragana arborescens. No asexual morph was observed on the herbarium specimens available for study. Thyronectria caraganae is closely related to T. austroamericana, which also occurs on fabaceous hosts and also forms large clusters of ascomata partly immersed in a stroma covered by a bright yellow scurf, but differs by ascospores of different size, shape and septation, by ascomata of dull olive brown colour and by the lack of a conspicuous zythiostroma-like asexual morph in nature (Hirooka et al. 2012; Jaklitsch and Voglmayr 2014).

Thyronectria chrysogramma Ellis \& Everh., Proc. Acad. nat. Sci. Philad. 42: 245. 1890. Fig. 3.

Synonyms. Mattirolia chrysogramma (Ellis \& Everh.) Sacc., Syll. fung. (Abellini) 9: 993. 1891. 

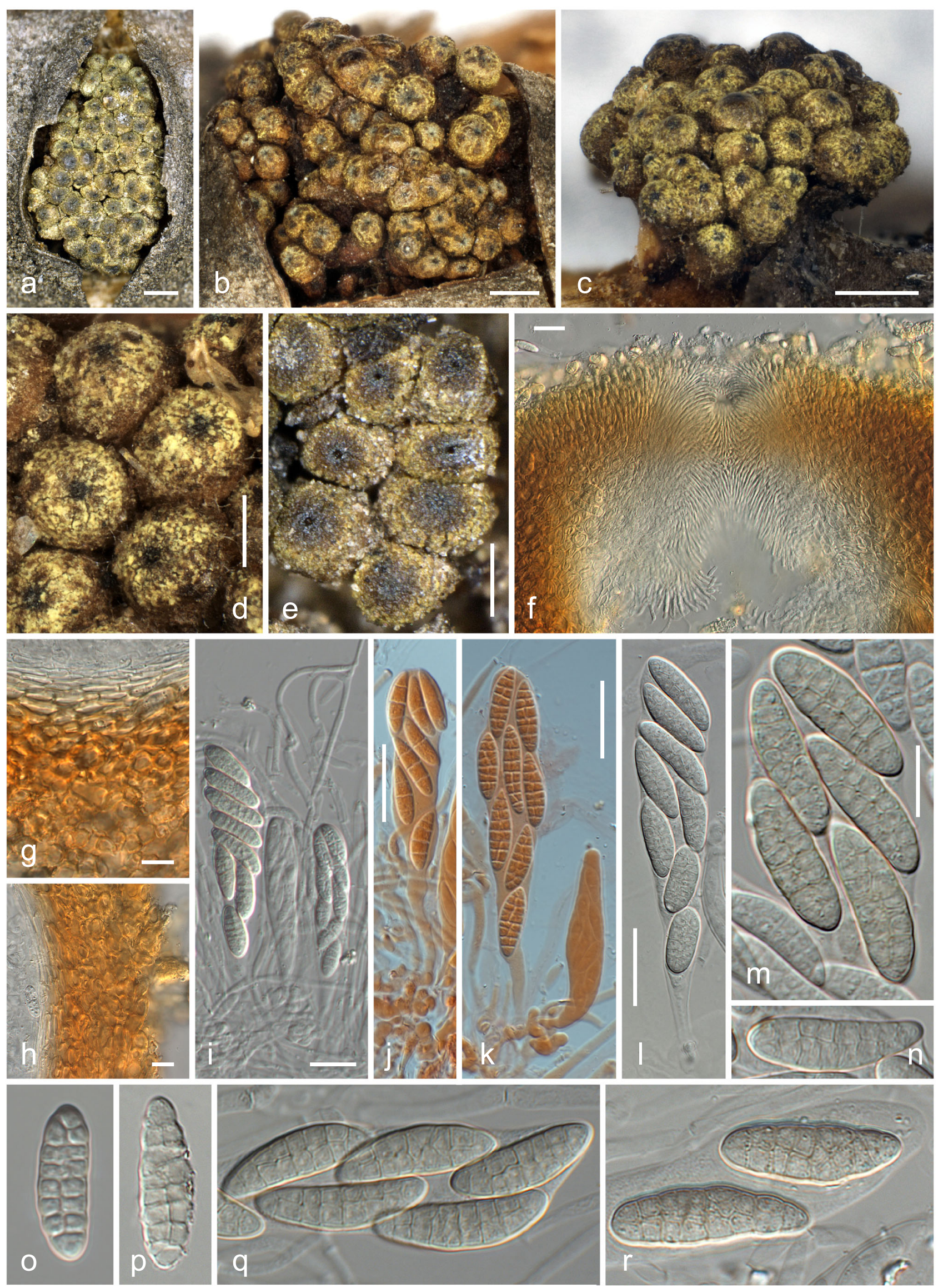
Nectria chrysogramma (Ellis \& Everh.) Rossman, Mem. N. Y. bot. Gdn 49: 259. 1989.

Thyronectroidea chrysogramma (Ellis \& Everh.) Seaver, Mycologia 1: 206. 1909.

Ascomata immersed and erumpent from bark, subglobose, $0.3-0.5 \mathrm{~mm}$ diam, scattered or aggregated, individually surrounded by yellowish stromatic tissue, sometimes immersed in soft, pulvinate, erumpent stromata to ca. $1 \mathrm{~mm}$ diam, covered with yellow to yellow-green scurf. Peridium reddish, weakly reacting in $3 \% \mathrm{KOH}$ and LA. Ostiolar area black, ostioles periphysate. Apical paraphyses numerous, richly branched, 1.5-5 $\mu \mathrm{m}$ wide. Asci (152-)150$195(-213) \times(25-) 27-33(-37) \mu \mathrm{m}(n=10)$, spore bearing part (102-)106-135(-145) $\mu \mathrm{m}(n=14)$ long, clavate, containing 8 biseriately arranged ascospores; apex undifferentiated. Ascospores (24-)28.7-34.5(-37) × (10-)12.5-15(-17.3) $\mu \mathrm{m}$, $1 / \mathrm{w}=(1.6-) 2.1-2.5(-3.2)(n=100)$, first hyaline and oblong, turning yellowish and finally olive-brown, becoming medium to reddish-brown in old herbarium specimens, and oblong or ellipsoid, with 4-9(-11) transverse and (1-)2-3 conspicuously closely inserted longitudinal eusepta, smooth.

Cultures and asexual morph: On MEA colony up to $58 \mathrm{~mm}$ diam after 20 days at room temperature; surface cream, with cottony tufts of aerial hyphae, turning rosy from the centre due to conidial masses; reverse cream to pale orange. On CMD colony up to $62 \mathrm{~mm}$ diam after 20 days at room temperature; white, conidiation sparse. Conidiation on phialides or hyphal pegs. Phialides (4.5-)6.5-11(-16) × (2.3-)2.5-3.2(-3.5) $\mu \mathrm{m}$ $(n=33)$, formed directly on hyphae, mostly solitary, terminal or lateral, flask-shaped to cylindrical. Pegs on hyphal cells mostly close to the septa, $(0.9-) 1.5-4.3(-6.8) \times(1.1-) 1.3-$ $2.7(-5.2) \mu \mathrm{m}(n=51)$. Conidia mainly formed on pegs, $(3.8-) 5.0-7.0(-9.6) \times(1.3-) 1.8-2.7(-3.4) \mu \mathrm{m}$, $1 / \mathrm{w}=(1.9-) 2.3-3.1(-4.3)(n=221)$, ellipsoid to allantoid, unicellular, hyaline, smooth, eguttulate or with few minute, often subterminal guttules, budding.

Distribution: North America

Ecology: Only known from bark of Ulmus americana, possibly fungicolous.

Specimen examined: Canada, Ontario, Ottawa, on bark of Ulmus americana, 24 Dec 2015, J. Mack (WU 35942, culture $\mathrm{TCH}=$ CBS 141087)

Notes: We provide here an extended description of Jaklitsch and Voglmayr (2014), which was based on the holo- and paratype, to include characters of the sexual morph in fresh condition, as well as culture characteristics and morphology of the asexual morph. The characters of the fresh collection agree well with the type material, which was illustrated in Checa et al. (2013; as Mattirolia chrysogramma) and Jaklitsch and Voglmayr (2014). As in type material, most perithecia are not aggregated into larger stromatic groups but occur solitarily and scattered in the fresh collection. Phylogenetic data place this species within the genus
Thyronectria, confirming the conclusions based on morphological analyses. However, a closer relationship to the European Thyronectria species with green to brown ascospores does not receive support, and its closest relatives within Thyronectria remain unclear.

Thyronectria concentrica (Mont. \& Fr.) Voglmayr \& Jaklitsch, comb. nov. Figs. 4, 5.

MycoBank: MB 817628

Basionym. Tubercularia concentrica Mont. \& Fr., in Montagne, Ann. Sci. Nat., Bot., sér. 2 6: 28 (1836).

Synonyms. Sphaeria miltina Durieu \& Mont., in Durieu, Expl. Sci. Algérie, Bot. I, Flore d'Algérie: 477. 1848 [18461849].

Allantonectria miltina (Mont.) Weese, in Höhnel \& Weese, Ann. mycol. 8(3): 467 (1910).

Nectria miltina (Mont.) Mont., Syll. gen. sp. crypt. (Paris): 225 (1856).

Nectriella miltina (Mont.) Sacc., Michelia 1(no. 3): 278 (1878).

Stromata erumpent through leaf epidermis, up to $2.5 \mathrm{~mm}$ diam, pulvinate, tubercular, orange to dark reddish brown when dry, inside yellow, $\mathrm{KOH}+$ red, LA+ yellow, pseudoparenchymatous, cells forming textura angularis to $t$. globulosa, intergrading with ascomatal wall. Ascomata superficial on the hypostroma, commonly surrounded by epidermis flaps, scattered to aggregated in groups of (2-)5-75, subglobose to globose, sometimes with a depressed apical region upon drying, 145-245 $\mu \mathrm{m}$ high, (145-)162$198(-240) \mu \mathrm{m}$ diam $(n=133)$, varying in colour from orange, red to dark reddish-brown, apical region darker when young, concolorous with age, $\mathrm{KOH}+$ deep to blackish red, LA+ yellow, entirely covered by yellow scurf of minute amorphous particles when young. Peridium 25-50 $\mu \mathrm{m}$ thick, consisting of a thin $(6-13 \mu \mathrm{m})$ inner layer of elongate, thinwalled, hyaline cells forming a textura prismatica and an outer ca. 20-40 $\mu \mathrm{m}$ thick layer of thick-walled cells 5$14 \mu \mathrm{m}$ diam, forming a textura globulosa or $t$. angularis, of pigmented walls about $1.5 \mu \mathrm{m}$ thick with a distinct $\mathrm{pH}$ dependent colour change, violaceous-red in $3 \% \mathrm{KOH}$, yellow in LA. Ostiolar region flat-umbilicate, usually darker than the main part of the perithecium when young. Ostiole periphysate, ca. 10-17 $\mu \mathrm{m}$ wide. Periphyses numerous, ca. $2 \mu \mathrm{m}$ thick. Apical paraphyses numerous, indistinct in $\mathrm{KOH}$, hanging down to the base of the asci, richly branched and anastomosing, consisting of inflated cells readily disarticulating upon pressure, $2-4.5 \mu \mathrm{m}$ wide. Asci narrowly clavate, $(26-) 28-35(-41) \times(3.0-) 3.5-4.5(-5.0) \mu \mathrm{m}(n=35)$, with variable stipe and undifferentiated apex, 8-spored; ascospores biseriate above, uniseriate below. Ascospores allantoid to short-cylindrical, rounded at both ends, $(3.3-) 4.3-5.5(-7.3) \times(0.9-) 1.2-1.6(-2.0) \mu \mathrm{m}$, $\mathrm{l} / \mathrm{w}=(2.5-) 3.1-4.2(-5.9)(n=595)$, aseptate, hyaline, smooth, not budding in the ascus. 

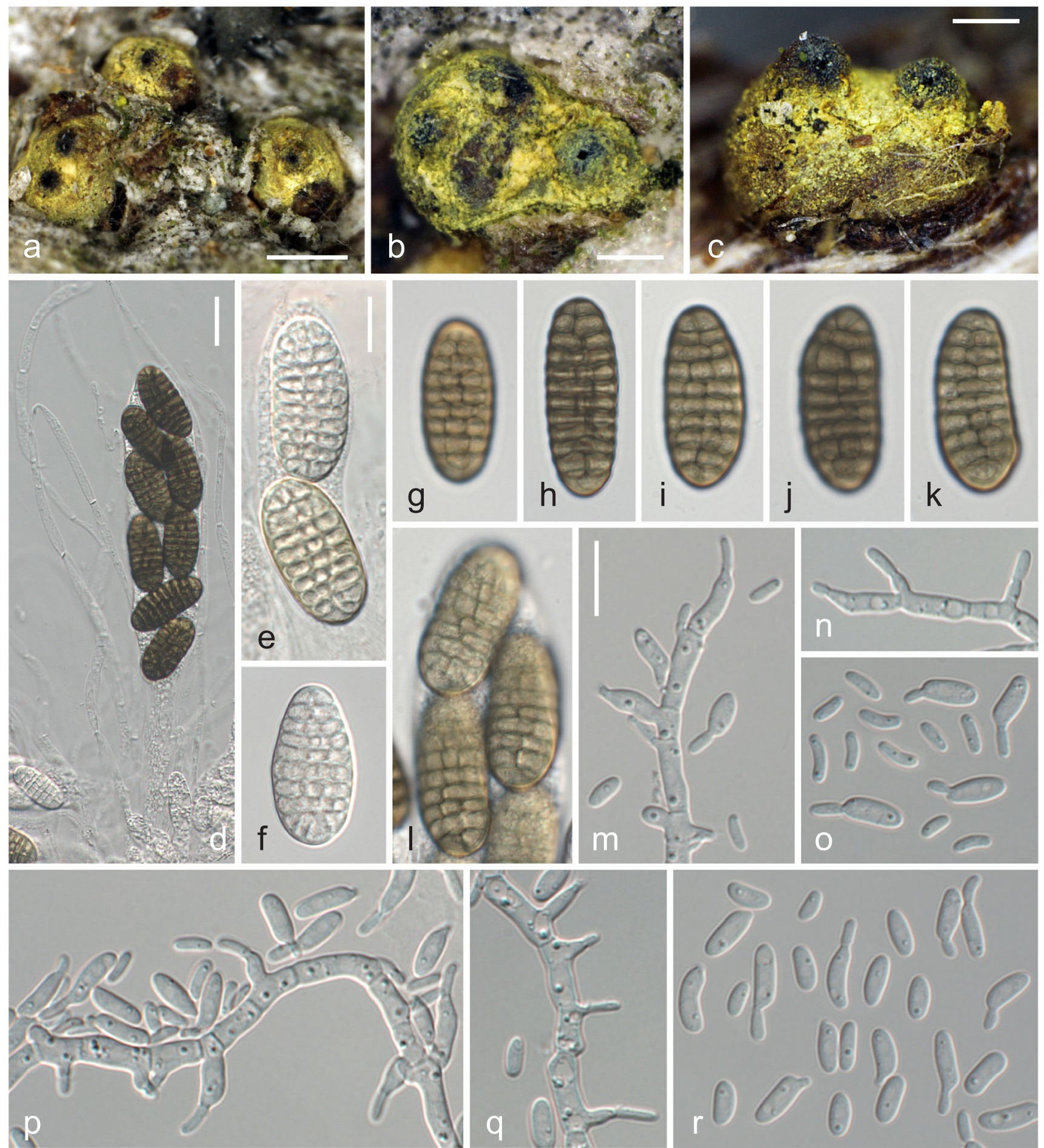

Fig. 3 Thyronectria chrysogramma (WU $35942=\mathrm{TCH})$. a-c Stromata. d Apical paraphyses and ascus. e- $\mathbf{I}$ Vital ascospores (e, $\mathbf{f}$ immature; $\mathbf{g}-\mathbf{I}$ mature). $\mathbf{m}, \mathbf{n}, \mathbf{p}, \mathbf{q}$ Effuse conidiation on hyphae showing pegs and

phialides (MEA, RT, 2 days). o, $\mathbf{r}$ Conidia (MEA, RT, 2 days); $\mathbf{d}-\mathbf{r}$ in water. Scale bars (a) $500 \mu \mathrm{m}$; (b, c) $200 \mu \mathrm{m}$; (d) $20 \mu \mathrm{m}$; (e-r) $10 \mu \mathrm{m}$ 
Asexual morph on natural substrates Synnematous, developing below the epidermis, orange to orange brown, in young stage translucent through epidermis as circular to elongate pale yellow to bright orange spots $0.3-1.3 \mathrm{~mm}$ diam, becoming free after rupturing of the epidermis, forming a fissured column of tightly packed septate yellowish, 2.5-5.5 $\mu \mathrm{m}$ thick hyphae. Phialides (4.3-)4.5-6.8(-11.2) × (2.3-)2.9-3.8(-4.9) $\mu \mathrm{m}(n=62)$, densely aggregated on outermost hyphae of the column, mostly solitary, lateral, flask-shaped, sometimes curved. Conidia (2.7-)3.5-4.2(-4.9) $\times(1.1-) 1.4-1.7(-2)$ $\mu \mathrm{m}, 1 / \mathrm{w}=(1.8-) 2.2-2.9(-3.7)(n=201)$, ellipsoid to slightly allantoid, unicellular, hyaline, smooth, eguttulate or with few minute, often subterminal guttules.

Asexual morph in pure culture On MEA colony up to $46 \mathrm{~mm}$ diam after 7 days at room temperature; surface cream, with tufts of aerial mycelium appressed to hyphal strands, turning pink from the centre due to conidial masses; reverse cream, conidiation starting on superficial substrate hyphae, later mainly on aerial hyphal strands. On CMD colony up to $59 \mathrm{~mm}$ diam after 7 days at room temperature; white, aerial hyphae sparse, conidiation mainly on superficial substrate hyphae. Conidiophores emerging as fasciculate side branches on strands of parallel hyaline aerial hyphae, short, 2-4.3 $\mu \mathrm{m}$ wide, simple, with few verticils of 2-3 branches. Conidiation on phialides or hyphal pegs. Phialides $(4.5-) 6.0-9.2(-10.5) \times(2.5-) 3.0-3.7(-4.3) \mu \mathrm{m}(n=40)$, formed directly on hyphae or on short conidiophores, mostly solitary or in whorls of 2-3, terminal or lateral, flask-shaped to cylindrical, straight, curved, mostly inequilateral. Pegs on hyphal cells $(0.8-) 1.1-3.2(-5.2) \times 1-1.7(-2.2) \mu \mathrm{m}(n=22)$. Conidia on surface hyphae $(3.0-) 4.5-7(-9.7) \times(1.3-) 1.5-$ $2.5(-3.7) \mu \mathrm{m}, 1 / \mathrm{w}=(1.8-) 2.4-3.4(-4.8)(n=103)$, on aerial hyphal strands $(3.2-) 3.5-4.3(-5.5) \times(1.3-) 1.6-1.8(-2) \mu \mathrm{m}$, $\mathrm{l} / \mathrm{w}=(1.8-) 2.1-2.5(-3.2)(n=100)$, ellipsoid to slightly allantoid, unicellular, hyaline, smooth, eguttulate.

Distribution: Africa, Mediterranean Europe, North America.

Ecology: On dead leaves of Agave spp.

Typification: France, Perpignan, on Agave americana, ex Herb. C. Montagne (K(M) 201845!, lectotype of Tubercularia concentrica here designated; K(M) 203419!, K(M) 203420! isotypes). Algeria, near Mustapha, on Agave americana, 22 Dec. 1839, M. C. Durieu (PC 0723442!, lectotype of Sphaeria miltina here designated). Algeria, without place, date and collector, Herb. C. Montagne (PC 0723441!, PC 0723446!, isotypes of Sphaeria miltina).

Other material studied (all on dead leaves of Agave americana): Algeria, Alger, 22 Dec. 1839, M. C. Durieu (PC 0723443); ibid., 21 Dec. 1839, M. C. Durieu (PC 0723439); ibid., 15 Jan. 1840, M. C. Durieu (PC 0723438). Greece, Corfu, Mon repos, Apr. 1912, K. Rechinger (W 191410028); ibid., same date and collector, in Rehm, Ascomyc.
Fig. 4 Thyronectria concentrica, sexual morph. a-h Stromata/ascomata (a-e with yellow scurf, $\mathbf{h}$ cupulate). $\mathbf{i}, \mathbf{j}$ Peridium around ostiolar region in LA (i) and $3 \% \mathrm{KOH}(\mathbf{j})$. k. Asci with ascospores and apical paraphyses (in Congo Red). l. Network of apical paraphyses. m, n Asci. o-q Ascospores (all in $3 \% \mathrm{KOH}$ except where noted). a, d W 1973-00252; b, j, l-n, p W 1912-3086; c, e, f, o W 1914-10028; g, i W 1914-9263; h, q W 1904-4875); k W 1914-9263. Scale bars (a, b) $100 \mu \mathrm{m} ;(\mathbf{b}-\mathbf{f}, \mathbf{h})$ $200 \mu \mathrm{m}$; (g) $500 \mu \mathrm{m}$; (i-n) $10 \mu \mathrm{m}$; (o-q) $5 \mu \mathrm{m}$

1962b (W 1914-9263). Italy, Südtirol, Arco-Meran, 1911, W. Dittrich-Kalkhoff, in Rehm, Ascomyc. 1962 (W1912-3086, W1973-00252); at shore of Lago di Garda, without date, Duby, in Rabenhorst, Herb. Mycol. II 631 (W1923-2100); Napoli, Botanical Garden, Cesati, in Rabenhorst, Fungi Eur. Exs. 1828a (sexual morph, labelled Nectria miltina), 1828b (asexual morph, labelled Tubercularia concentrica) (W 201602661); Sicilia, Messina, Motta Camastra, Gole Alcantara Parco Botanico e Geologico, 19 June 2016, H. Voglmayr \& W. Jaklitsch (WU 35949). Montenegro, Ulcinj, 10 Apr. 1903, F. Bubak, in Vestergren, Micromyc. Rar. Sel. Praec. Scand. 829 (W 1904-4875). Spain, Islas Canarias, La Gomera, Juego de Bolas, 20 Mar. 2016, H. Voglmayr \& I. Greilhuber (WU 35943; culture from asexual morph ALLA); La Gomera, Chipude, 23 Mar. 2016, H. Voglmayr \& I. Greilhuber (WU 35944; culture from sexual morph ALLM).

Notes: This species has been commonly known as Allantonectria miltina (see Hirooka et al. 2012). In older literature (e.g., Saccardo 1878, 1883), Tubercularia concentrica has been given as the asexual morph of $A$. miltina, but Lowen (1991) and Hirooka et al. (2012) did not mention the name in their synonymies. Hirooka et al. (2012) did not record an asexual morph from natural substrates. In one of our recent collections, we found a synnematous asexual morph developing below the host epidermis, and its connection with the sexual morph was subsequently proven by pure cultures and sequence data. Investigation of three isotype specimens of Tubercularia concentrica revealed that they fully match the asexual morph of our recent collection, and we here select the well-developed specimen K(M) 201845 as lectotype. As Tubercularia concentrica is older than Sphaeria miltina, the epithet concentrica has to be used, which is here combined in Thyronectria (see discussion below).

The asexual morph produced on SNA has been described as trichoderma-like by Hirooka et al. (2012). In our cultures on $2 \%$ MEA, conidiation started on surface hyphae similar to other Thyronectria species, but was later primarily present on the hyphal strands of the aerial mycelium.

Thyronectria concentrica appears to be widespread in the Mediterranean where its main host, Agave americana, is commonly cultivated and naturalised. Like its host, it is assumed to originate from North America. Based on sequence data (Fig. 1), we do not accept synonymy of $T$. concentrica and T. yuccae, which mainly differ in their hosts (Agave vs. Yucca; see below) and by different ascospore sizes. In addition, 

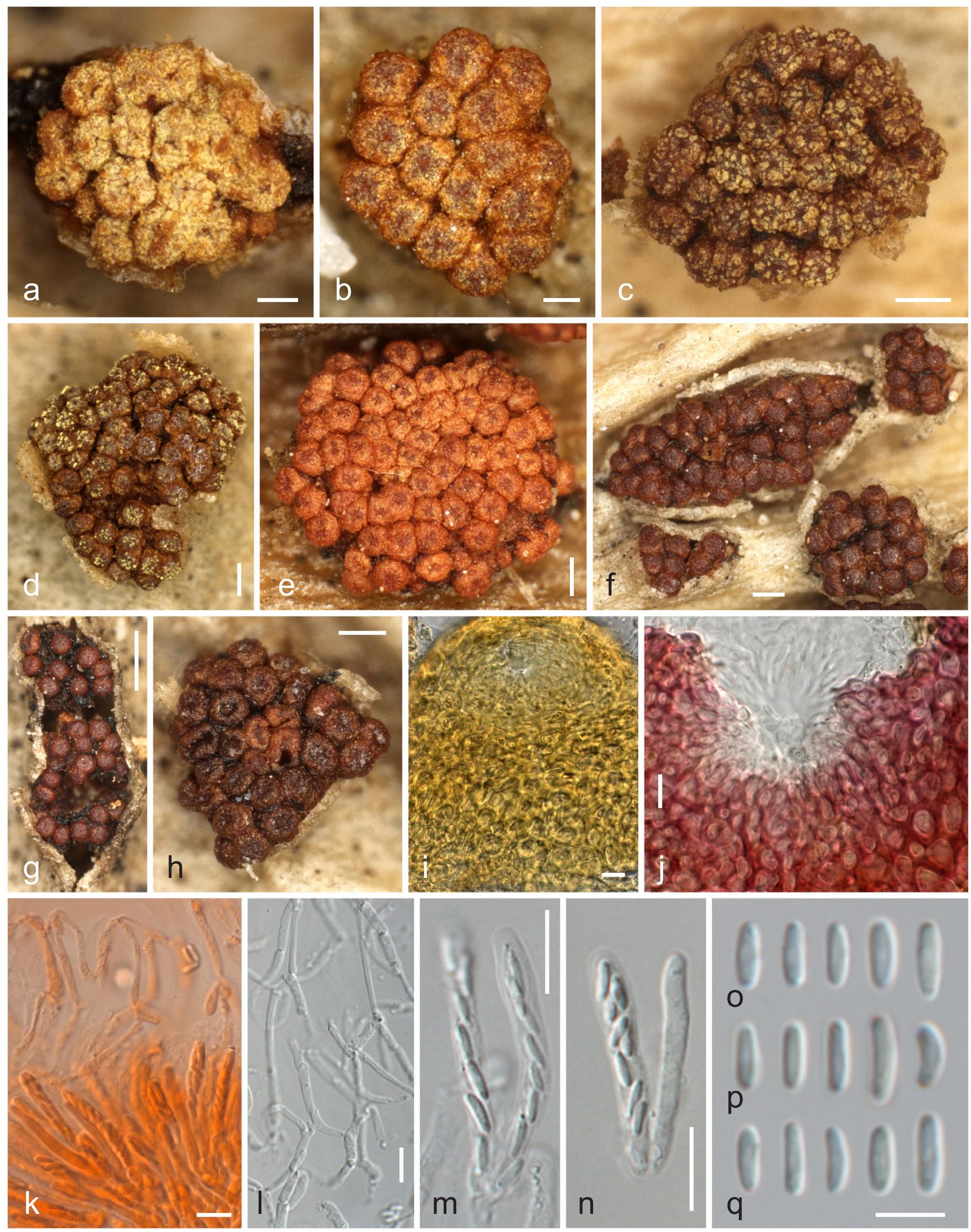
T. concentrica commonly has more ascomata per stroma (up to 75 vs. up to 30 in T. yuccae). We include here a short description and illustration of $T$. concentrica in addition to the detailed description by Hirooka et al. (2012, under Allantonectria miltina) to facilitate comparison with T. yuccae and to describe the apical paraphyses and the asexual state on the natural substrate, which have not yet been documented for this species. As in all Thyronectria species we have investigated (Jaklitsch and Voglmayr 2014; Checa et al. 2015), apical paraphyses are numerous and more or less persistent, but they are delicate, easily disarticulating and therefore only seen after careful ascoma preparation preferably in $\mathrm{KOH}$ (herbarium specimens) or water (fresh samples).

The collection data (year and collector) of the specimen given as holotype of Sphaeria miltina by Hirooka et al. (2012) do not agree with the protologue and cannot represent a type. Lowen (1991) designated a specimen from Herb. Montagne deposited in PC as lectotype, but the specimen labels of the two extant collections from Herb. Montagne do not bear the collection data she gave in the text, and the packages contain no information about lectotypification. In addition, the specimens were rearranged on a new sheet, with one fragment in PC 0723446 and four fragments in PC 0723441, whereas Lowen (1991) mentions the presence of two fragments in the specimen she examined, so it is unclear which specimen she selected. We here select specimen PC 0723442 from Herb. Durieu as lectotype of Sphaeria miltina, which is the only authentic specimen from PC on which Mustapha, the place mentioned in the protologue, is given on the original label. The two specimens from Herb. Montagne without place and date are considered to represent isotypes.

Thyronectria yuccae (Earle) Voglmayr \& Jaklitsch, comb. nov. Fig. 6.

MycoBank: MB 817629

Basionym. Allantonectria yuccae Earle in Greene, Plant. Bak. 2(1): 11 (1901).

Stromata erumpent through leaf epidermis, up to $1.2 \mathrm{~mm}$ diam, pulvinate, tubercular, orange to dark reddish-brown when dry, inside yellow, $\mathrm{KOH}+$ red, LA+ yellow, pseudoparenchymatous, cells forming textura angularis to $t$. globulosa, intergrading with the ascomatal wall, 4-12 $\mu \mathrm{m}$ diam. Ascomata superficial on the hypostroma, commonly surrounded by epidermis flaps, scattered to aggregated in groups of (2)5-20(30), subglobose to globose, sometimes with a depressed apical region upon drying, 140-170 $\mu \mathrm{m}$ high, (125-)155-190(-230) $\mu \mathrm{m}$ diam $(n=121)$, varying in colour from orange, red to dark reddish-brown, apical region commonly slightly darker when young, concolorous with age, $\mathrm{KOH}+$ deep to blackish-red, LA + yellow, entirely covered by yellow scurf of minute amorphous particles when young. Peridium 50-60 $\mu \mathrm{m}$ thick, consisting of a thin (ca. 10$15 \mu \mathrm{m}$ ) inner layer of elongate, thin-walled, hyaline cells forming a textura prismatica and an outer ca. 40-45 $\mu \mathrm{m}$ thick
Fig. 5 Thyronectria concentrica, asexual morph. a-f Synnematous conidiomata on natural substrates (a-c in surface view, $\mathbf{d}-\mathbf{f}$ in side view after rupture of the host epidermis). $\mathbf{g}-\mathbf{j}$ Squash mounts of synnematous conidiophores with lateral phialides in $3 \% \mathrm{KOH}(\mathbf{g}, \mathbf{h})$ and water $(\mathbf{i}, \mathbf{j})$. $\mathbf{k}$, I Effuse conidiation on hyphae showing pegs and phialides (MEA, RT, 3 days). $\mathbf{n}-\mathbf{p}$ Conidiophores and phialides on aerial hyphal strands (MEA, RT, 7 days). $\mathbf{q}-\mathbf{t}$ Conidia [q, $\mathbf{r}$ from natural substrates, $\mathbf{s}$ from aerial strands (MEA, RT, 7 days), $\mathbf{t}$ from effuse sporulation (MEA, RT, 3 days)] (all in water except where noted). a, b, g, r K(M) 201845; c, e, f, i, j, q WU 35943; d K(M) 203419; h K(M) 203420; k-p, s, t WU 35944. Scale bars (a) $10 \mathrm{~mm}$; (b) $300 \mu \mathrm{m}$; (c-f) $100 \mu \mathrm{m} ;(\mathbf{g}-\mathbf{l}, \mathbf{n}-\mathbf{p}) 10 \mu \mathrm{m}$; (m) $50 \mu \mathrm{m} ;(\mathbf{q}-\mathbf{t}) 5 \mu \mathrm{m}$

layer of thick-walled cells 3-10 $\mu \mathrm{m}$ diam, forming a textura globulosa or $t$. angularis, of pigmented walls about $1-1.5 \mu \mathrm{m}$ thick with a distinct $\mathrm{pH}$-dependent colour change, violaceousred in $3 \% \mathrm{KOH}$, yellow in LA. Ostiolar region flat-umbilicate, commonly darker than the main part of the perithecium when young. Ostiole periphysate, ca. 10-20 $\mu \mathrm{m}$ wide. Periphyses numerous, ca. $2 \mu \mathrm{m}$ thick. Apical paraphyses numerous, indistinct in $\mathrm{KOH}$, extending to the base of the asci, richly branched and anastomosing, consisting of inflated cells easily disarticulating upon pressure, $1-4.5 \mu \mathrm{m}$ wide. Asci narrowly clavate, $(27-) 30-41(-48) \times(3.7-) 4-5(-5.8) \mu \mathrm{m}(n=$ $34)$, with variable stipe and undifferentiated apex, 8-spored; ascospores biseriate above, uniseriate below. Ascospores allantoid to short-cylindrical, rounded at both ends, $(4.5-) 5.5-7.3(-9.6) \times(1.1-) 1.4-1.8(-2.3) \mu \mathrm{m}$, $1 / \mathrm{w}=(2.7-) 3.5-4.7(-6.2)(n=301)$, aseptate, hyaline, smooth, not budding in the ascus.

Asexual morph on natural substrates: Not observed.

Distribution: North and Central America.

Ecology: On dead leaves of Yucca spp.

Type: USA, Colorado, Hermosa, on Yucca sp., March 1899, C.F. Baker (W 1901-6035!, isotype)

Other material studied: USA, California, Riverside County, near San Jacinto, Soboba Hot Springs, on dead leaves of Yucca schidigera, 6 Mar. 1955, H. E. Parks 9007, in California Fungi 1127 (W 1963-7695, W 1973-06127); Colorado, Boulder, on dead leaves of Yucca sp., Aug. 1950, F. Petrak 10127 (W 1971-14238); Leyden, on dead leaves of Yucca glauca, 2 May 1910, E. Bethel, (W 1981-08871); Nebraska, Valentine, on dead leaves of Yucca sp., 23 Feb. 1898, C.S. Shear, (W 1974-22484).

Notes: This species is the generic type of Allantonectria (Earle 1901), described from Yucca sp. collected in Colorado (USA). In combining the older Sphaeria miltina, which was described from Agave americana collected in Algeria, in Allantonectria, Höhnel and Weese (1910) synonymised A. yuccae with the older A. miltina, evidently based on similar ascospore sizes. This synonymy was also accepted by Hirooka et al. (2012), who cited specimens from both host genera, but only included sequences from a European accession from Agave americana in their phylogenies. Recently, sequences from an accession from 

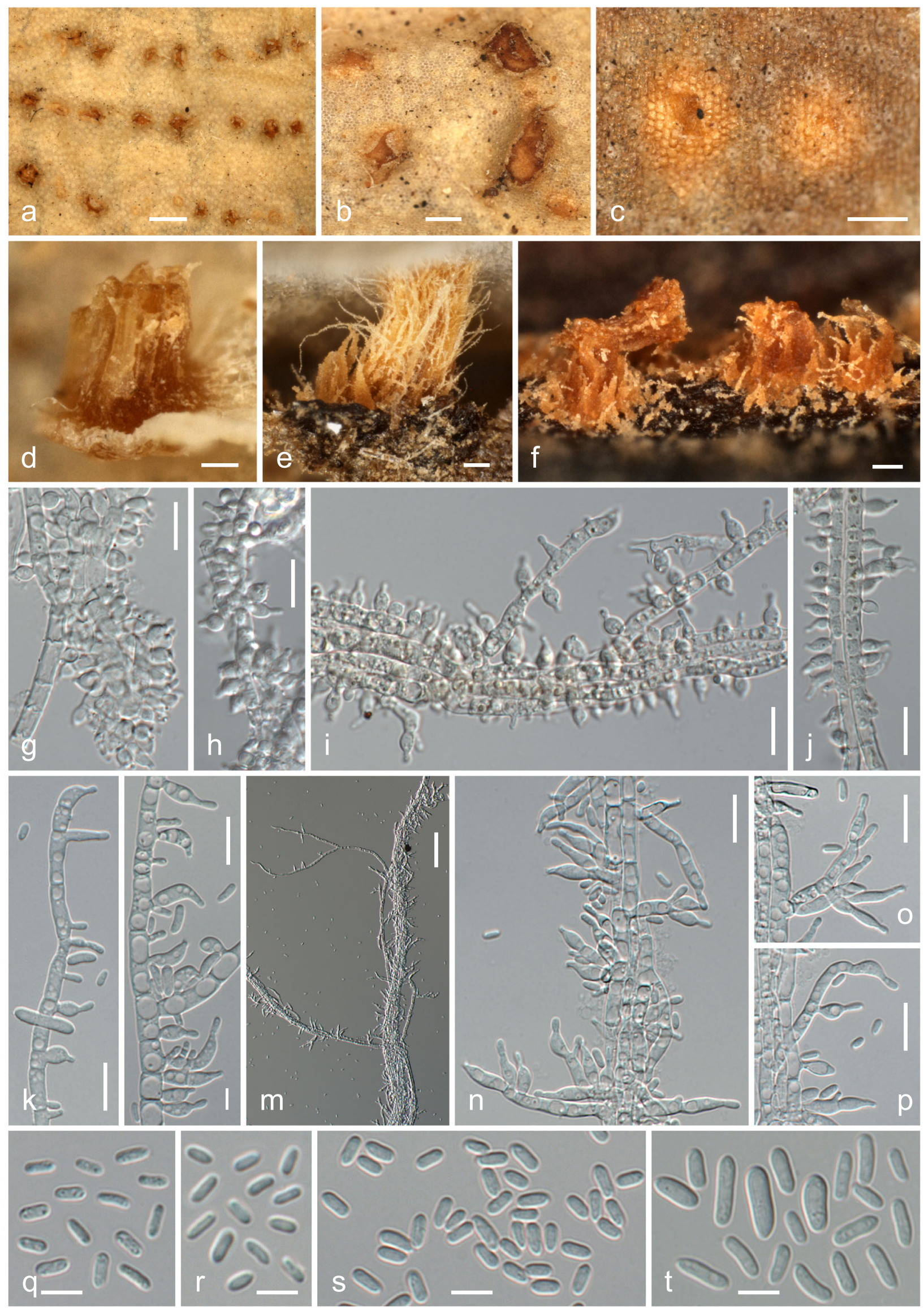
Yucca elata collected in Arizona (USA) became available (Lombard et al. 2015), which differ substantially from the European collections of T. concentrica (see also Fig. 1). We therefore re-investigated specimens from both host genera, including an isotype of A. yuccae deposited in W, and found that $A$. yuccae has larger ascospores compared to $T$. concentrica $((4.5-) 5.5-7.3(-9.6) \times(1.1-) 1.4-$ $1.8(-2.3)$ vs. $(3.3-) 4.3-5.5(-7.3) \times(0.9-) 1.2-1.6(-2.0)$ $\mu \mathrm{m})$. We therefore consider $A$. yuccae to represent a species distinct from $T$. concentrica, and it is here combined in Thyronectria.

Thyronectria zangii (Z.Q. Zeng \& W.Y. Zhuang) Voglmayr \& Jaklitsch, comb. nov.

MycoBank: MB 817630

Basionym. Nectria zangii Z.Q. Zeng \& W.Y. Zhuang, Mycotaxon 120: 69 (2012).

Synonym. Allantonectria zangii (Z.Q. Zeng \& W.Y. Zhuang) Z.Q. Zeng \& W.Y. Zhuang, Mycosystema 32(2): 294 (2013).

Holotype. China, Beijing, Donglingshan, alt. $1150 \mathrm{~m}$, on branches of Populus sp., 20 July 2011, Z.Q. Zeng \& H.D. Zheng 7684 (HMAS 251247, not seen).

Notes: Thyronectria zangii closely resembles $T$. concentrica and T. yuccae in its minute unicellular rod-shaped ascospores, but differs by thinner perithecial walls, narrower asci, and occurrence on twigs of Populus (Zeng and Zhuang 2012). Ascospore size of $T$. zangii $(3.5-5.5(-6) \times 0.9-1.2(-1.4) \mu \mathrm{m})$ is similar to that of $T$. concentrica revealed in the present study. Like for T. yuccae, no asexual morph has been recorded for T. zangii from natural substrates.

\section{Discussion}

Molecular phylogenetic analyses confirm the conclusions of Jaklitsch and Voglmayr (2014) that Thyronectroidea chrysogramma belongs to Thyronectria. However, it is not contained within the clade comprising European species with green to brown ascospores (formerly classified in Mattirolia), but its phylogenetic position within Thyronectria remains uncertain. In the MP analyses, it is placed basal to the Allantonectria-Thyronectria lineage, a position which does not receive support, whereas in the ML analyses it is placed in a basal position of the clade containing the species with yellowish to rosy spores, again without support.

While the Thyronectria-Allantonectria clade and Allantonectria are highly supported, the genus Thyronectria receives only low support in both MP and ML analyses (Fig. 1). It should be noted that, with the addition of species and markers, the medium to high internal support of a sister group relationship of Allantonectria to Thyronectria as revealed by Hirooka et al. (2012), has decreased significantly in subsequent publications (Jaklitsch and Voglmayr 2014; Checa et al. 2015), which casts
Fig. 6 Thyronectria yuccae. a Young hypostroma. b-h Stromata/ ascomata (b-d with yellow scurf): i. Peridium around ostiolar region in $3 \% \mathrm{KOH}$. j, $\mathbf{k}$ Asci with ascospores and apical paraphyses. I, $\mathbf{m}$ Asci. n, o Ascospores (all in $3 \% \mathrm{KOH}$ except where noted). a, b, e, j, m, o W 198108871; c, d, h, i, k, n W1912-3086; f W 1971-14238; g W 1901-6035 (isotype). Scale bars $(\mathbf{a}-\mathbf{h}) 200 \mu \mathrm{m}$; (i-m) $10 \mu \mathrm{m} ;(\mathbf{n}, \mathbf{o}) 5 \mu \mathrm{m}$

doubt on the status of Allantonectria as a separate genus. With the addition of A. zangii from Populus (Zeng and Zhuang 2013), monocotyledonous substrates are no longer distinctive for Allantonectria, and the only remaining difference between the two genera lies in the small, unicellular allantoid to rod-shaped ascospores of Allantonectria. Considering the highly diverse ascospore sizes, shapes, colours and septations prevailing in Thyronectria, we do not regard ascospore characters alone to be suitable for generic delimitation, and it appears justified to include Allantonectria in Thyronectria. The presence of persistent apical paraphyses and the asexual morph in pure culture, which were revealed in the present study, also correspond to Thyronectria. In the light of this morphological and molecular phylogenetic evidence, we argue for inclusion of Allantonectria in Thyronectria, and we formally combine the three accepted species of Allantonectria in Thyronectria.

Based on culturing and sequencing of recent collections as well as type studies, we were able to confirm that Tubercularia concentrica is the asexual morph of A. miltina, and we here provide an extended description of the asexual morph on natural substrates for the first time. Lowen (1991) and Rossman et al. (1999) mentioned Tubercularia sp. as asexual morph; however, without giving any description. Hirooka et al. (2012) did not find an asexual morph on natural substrates, probably due to its development within decaying leaves prior to ascomata, whereas they expected it to be pycnidial. At first sight, the synnematous conidiomata of $T$. concentrica do not fit the concept of Thyronectria, which was considered to be characterised by pycnidial conidiomata (Hirooka et al. 2012, under Pleonectria). However, not all Thyronectria species have pycnidial conidiomata, but some like $T$. roseovirens show effuse sporulation on natural substrates (Jaklitsch and Voglmayr 2014). Also, the "trichoderma"-like conidiation on aerial hyphal strands in pure culture are not unique for T. concentrica, but similar conidiation is also observed, e.g., in T. asturiensis (Jaklitsch and Voglmayr 2014). Therefore, although pycnidial asexual morphs are common within Thyronectria, they cannot be considered diagnostic for the whole lineage.

Thyronectria caraganae is revealed as the closest relative of T. austroamericana within the clade comprising species with yellowish to rosy ascospores. Apart from spore colour, species within this clade are characterised by ascomata surrounded by stromatic tissue (Hirooka et al. 2012; Jaklitsch and Voglmayr 2014). In addition, all species have muriform ascospores, which do not bud within the ascus or only rarely do so. All these characters are also present in T. caraganae. 

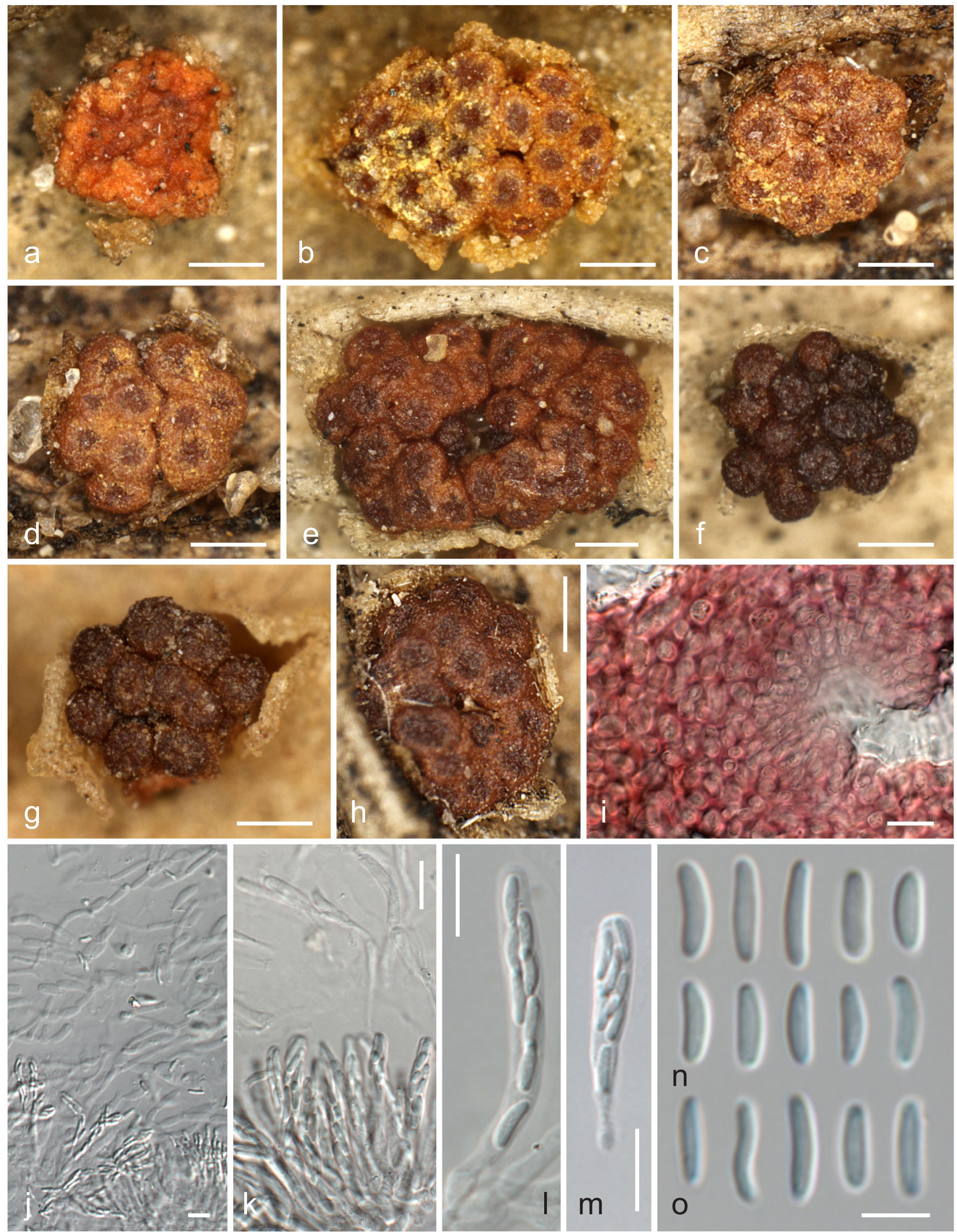
Remarkably, T. caraganae is so far only known from the Ukraine, although its host, Caragana arborescens, is widely planted throughout Europe at road banks and between fields as a shrub preventing soil erosion by wind. However, it appears to be much rarer than its host, and may be confined to areas of continental climate. Despite pronounced search, the fungus could not be found in eastern Austria where its host is commonly cultivated. In eastern Austria, Caragana arborescens is frequently colonised by another nectriaceous fungus with similar ecology, Stromatonectria caraganae (Jaklitsch and Voglmayr 2011a), which may be the reason for the absence of Thyronectria caraganae in this area. However, the latter is an example for the lack of biodiversity inventories, even in well-studied Central Europe. Despite its conspicuous bright red stromata, S. caraganae had not been recorded for more than 100 years after its description, although it not only persisted in its type locality, a botanical garden (Jaklitsch and Voglmayr 2011a), but also turned out to be very common on Colutea arborescens and Caragana arborescens, and sometimes Laburnum anagyroides (all members of the Fabaceae), in eastern Austria after more detailed investigations. The detection of $T$. caraganae on a widely distributed host once again demonstrates the need of biodiversity studies on corticolous ascomycetes in Europe, of which a substantial amount of species is still poorly known and undescribed (e.g., Voglmayr and Jaklitsch 2008, 2011, 2014; Jaklitsch and Voglmayr 2011a, b, 2014; Voglmayr et al. 2012, 2016; Jaklitsch et al. 2013, 2014, 2015, 2016; Checa et al. 2015).

Acknowledgments Open access funding provided by University of Vienna. We thank the fungarium curators of K, PC, W and Walter Till at WU for sending and managing collections, Jonathan Mack for kindly providing the fresh collection of Thyronectria chrysogramma and Prof. Irina O. Dudka (M.G. Kholodny Institute of Botany, NAS of Ukraine) for the opportunity to obtain and investigate duplicates of the nectriaceous fungi specimens that are stored in the herbarium $\mathrm{KW}$.

Open Access This article is distributed under the terms of the Creative Commons Attribution 4.0 International License (http:// creativecommons.org/licenses/by/4.0/), which permits unrestricted use, distribution, and reproduction in any medium, provided you give appropriate credit to the original author(s) and the source, provide a link to the Creative Commons license, and indicate if changes were made.

\section{References}

Checa J, Blanco MN, Moreno G (2013) Contributions to the family Thyridiaceae. New data on Sphaeria mutabilis. Mycotaxon 125: 149-164
Checa J, Jaklitsch WM, Blanco MN, Moreno G, Tello S, Olariaga I, Voglmayr H (2015) Two new species of Thyronectria from Mediteranean Europe. Additions to genus. Mycologia 107:1314 1322

Earle FS (1901) Fungi. In: Plantae Bakerianae, vol. II (ed. Greene E.L.): 1-30

Hall TA (1999) BioEdit: a user-friendly biological sequence alignment editor and analysis, program for Windows 95/98/NT. Nucleic Acids Symp Ser 41:95-98

Hirooka Y, Rossman AY, Samuels GJ, Lechat C, Chaverri P (2012) A monograph of Allantonectria, Nectria, and Pleonectria (Nectriaceae, Hypocreales, Ascomycota) and their pycnidial, sporodochial, and synnematous anamorphs. Stud Mycol 71:1-210

Höhnel F, Weese J (1910) Zur Synonymie in der Gattung Nectria. Ann Mycol 8:464-468

Jaklitsch WM (2009) European species of Hypocrea Part I. The greenspored species. Stud Mycol 63:1-91

Jaklitsch WM, Voglmayr H (2011a) Stromatonectria gen. nov. and notes on Myrmaeciella. Mycologia 103:431-440

Jaklitsch WM, Voglmayr H (2011b) Nectria eustromatica sp. nov., an exceptional species with a hypocreaceous stroma. Mycologia 103:209-218

Jaklitsch WM, Voglmayr H (2014) Persistent hamathecial threads in the Nectriaceae, Hypocreales: Thyronectria revisited and re-instated. Persoonia 33:182-211

Jaklitsch WM, Réblová M, Voglmayr H (2013) Molecular systematics of Woswasia atropurpurea gen. et sp. nov. (Sordariomycetidae), a fungicolous ascomycete with globose ascospores and holoblastic conidiogenesis. Mycologia 105:476-485

Jaklitsch WM, Fournier J, Rogers JD, Voglmayr H (2014) Phylogenetic and taxonomic revision of Lopadostoma. Persoonia 32:52-82

Jaklitsch WM, Fournier J, Dai DQ, Hyde KD, Voglmayr H (2015) Valsaria and the Valsariales. Fungal Divers 73:159-202

Jaklitsch WM, Gardiennet A, Voglmayr H (2016) Resolution of morphologybased taxonomic delusions: Acrocordiella, Basiseptospora, Blogiascospora, Clypeosphaeria, Hymenopleella, Lepteutypa, Pseudapiospora, Requienella, Seiridium and Strickeria. Persoonia 37: $82-105$

Lombard L, van der Merwe NA, Groenewald JZ, Crous PW (2015) Generic concepts in Nectriaceae. Stud Mycol 80:189-245

Lowen R (1991) A monograph of the genera Nectriella Nitschke and Pronectria Clements with reference to Charonectria, Cryptonectriella, Hydronectria and Pseudonectria. $\mathrm{PhD}$ dissertation, City University of New York

Rossman AY, Samuels GJ, Rogerson CT, Lowen R (1999) Genera of Bionectriaceae, Hypocreaceae and Nectriaceae (Hypocreales, Ascomycetes). Stud Mycol 42:1-248

Saccardo PA (1878) Enumeratio pyrenomycetum hypocreaceorum hucusque cognitorum systemate carpologico dispositorum. Michelia 1:277-325

Saccardo PA (1883) Sylloge Fungorum II: 448

Silvestro D, Michalak I (2012) raxmlGUI: a graphical front-end for RAxML. Org Divers Evol 12:335-337

Stamatakis E (2006) RAxML-VI-HPC: maximum likelihood-based phylogenetic analyses with thousands of taxa and mixed models. Bioinformatics 22:2688-2690

Swofford DL (2002) PAUP* 4.0b10: phylogenetic analysis using parsimony (*and other methods). Sinauer, Sunderland

Voglmayr H, Jaklitsch WM (2008) Prosthecium species with Stegonsporium anamorphs on Acer. Mycol Res 112:885-905

Voglmayr H, Jaklitsch WM (2011) Molecular data reveal high host specificity in the phylogenetically isolated genus Massaria (Ascomycota, Massariaceae). Fungal Divers 46:133-170

Voglmayr H, Jaklitsch WM (2014) Stilbosporaceae resurrected: generic reclassification and speciation. Persoonia 33:61-82 
Voglmayr H, Rossman AY, Castlebury LA, Jaklitsch W (2012) Multigene phylogeny and taxonomy of the genus Melanconiella (Diaporthales). Fungal Divers 57:1-44

Voglmayr H, Gardiennet A, Jaklitsch WM (2016) Asterodiscus and Stigmatodiscus, two new apothecial dothideomycete genera and the new order Stigmatodiscales. Fungal Divers (in press)
Zeng ZQ, Zhuang WY (2012) A new species of Nectria on Populus from China. Mycotaxon 120:67-73

Zeng ZQ, Zhuang WY (2013) A new combination of Allantonectria (Hypocreales). Mycosystema 32:292-296 